\title{
Osteoprogenitor cells can enhance early bone formation in critical bone defects in dogs
}

\author{
Endrigo Gabellini Leonel Alves ${ }^{1,2^{*}}$ Rogéria Serakides ${ }^{2}$ Isabel Rodrigues Rosado ${ }^{1,2}$ \\ Omar Leonardo Aristizabal Paez ${ }^{2}$ Jéssica Alejandra Castro Varon ${ }^{2}$ Felipe Nemer Machado ${ }^{2}$ \\ Fabíola Bono Fukushima ${ }^{2}$ Alfredo Miranda Góes ${ }^{2}$ Cleuza Maria de Faria Rezende ${ }^{2}$
}

${ }_{1}^{1}$ Universidade de Uberaba (UNIUBE), Uberaba, MG, Brasil. E-mail:endrigoglalves@gmail.com. "Corresponding author. ${ }^{2}$ Universidade Federal de Minas Gerais (UFMG), Belo Horizonte, MG, Brasil.

ABSTRACT: The aim of this study was to evaluate the effect of osteoprogenitor cells derived from mesenchymal stem cells from adipose tissue (OC-AD-MSCS), and differentiated into osteoblasts, in the treatment of critical bone defects in dogs. Adipose tissue derived mesenchymal stem cells (AD-MSCS) were subjected to osteogenic differentiation for 21 days and used in the treatment of bone defects in dogs radius. Either three experimental groups were bone defects treated with OC-AD-MSCs (OC), defects filled with autogenous bone (Control- $C+$ ), or empty defects (Control- C-). Bone regeneration was assessed by radiology, densitometry, and histomorphometry. The area of new bone formation was higher in the OC group compared to the control group (C-) on postoperative day 15. Defects treated with OC-AD-MSCs showed greater neovascularization than the other two groups at 90 days. We concluded that treatment with OC-AD-MSCs increased the area of new bone formation 15 days after surgery; however, it didn't complete the bone union in critical bone defects in the radius of dogs at 90 days.

Key words: bone regeneration, orthopedics, cellular therapy, fracture non-union.

Células osteoprogenitoras podem aumentar a formação óssea precoce em defeitos ósseos críticos de cães

RESUMO: O objetivo deste estudo foi avaliar o efeito das células osteoprogenitoras derivadas de células tronco mesenquimais do tecido adiposo (CO-CTM-AD) no tratamento de defeitos ósseos críticos de cães. As células tronco mesenquimais do tecido adiposo (CTM-AD) foram submetidas à diferenciação osteogênica por 21 dias e usadas no tratamento de defeitos ósseos em rádios de cães. Foram constituídos três grupos experimentais: defeitos ósseos tratados com CO-CTM-AD (OC), defeitos preenchidos com osso autógeno (C+) e defeitos não preenchidos (C-). A regeneração óssea foi avaliada por meio de exames radiográficos, densitométricos e histomorfométricos. A área de neoformação óssea foi maior no grupo OC em relação ao grupo C- no $15^{\circ}$ dia de pós-operatório. Os defeitos tratados com CO-CTMAD mostraram maior neovascularização que os demais grupos aos 90 dias de avaliação. Conclui-se que o tratamento com CO-CTM-AD aumentou a área de osso neoformado no $15^{\circ}$ dia de pós-operatório, mas não foi suficiente para que houvesse a completa união óssea em defeitos ósseos críticos no rádio de cães aos 90 dias.

Palavras-chave: regeneração óssea, ortopedia, terapia celular, não união de fraturas.

\section{INTRODUCTION}

One of the greatest challenges of human and veterinary orthopedics is the treatment of critical bone defects, characterized by large bony losses and the inability to regenerate naturally without additional treatment. Generally, critical bone defects are treated with bone grafts, preferably autogenous, that favor regeneration of the bone tissue by means of osteoconduction, osteoinduction, and osteogenesis (ALVES et al., 2015b). However, some drawbacks such as increased surgical time, complications at the collection site, local embrittlement, and a limited amount of bone graft collected, are associated with the use of autogenous bone grafts, despite this method being considered the best to date (KRAUS \& BAYER, 2012). Because of this, studies have been devoted to the search for efficient alternatives to replace this form of grafting, and stem cell therapy is one of the most promising alternatives (KRAUS \& KIRKER-HEAD, 2006; KANG et al., 2012). Mesenchymal stem cells (MSCs) are multipotent 
cells, with self-renewal and differentiation functions, found among differentiated cells in tissue. These cells contribute to the different cell types of the tissue in which they reside (STRIOGA et al., 2012).

To improve osteogenic differentiation of adipose-derived mesenchymal stem cells (ADMSCs), this step can be performed in vitro before clinical use (LIU et al., 2013). Thus, the aim of this study was to evaluate osteoprogenitor cells derived from mesenchymal stem cells from adipose tissue (OC-AD-MSCs) in the treatment of critical bone defects in dogs radio.

\section{MATERIALS AND METHODS}

\section{Adipose MSCs collection and cuture}

Three healthy male mongrel dogs (aproximatively 2 years-old, body mass of $18 \pm 1,6 \mathrm{~kg}$ ) were used as AD-MSC donors. Adipose tissue collection was performed on dogs under general anesthesia (Propofol). For analgesia, meloxicam (Maxicam, Ouro Fino, Brazil) $\left(0.2 \mathrm{mg} \mathrm{kg}^{-1} \mathrm{IM}\right)$ was used every 24 hours for three days. Adipose tissue $\left(1 \mathrm{~cm}^{3}\right.$ of each animal) was collected from the subcutaneous gluteal region and processed according to ALVES et al. (2014). Briefly, the samples were washed with $0.15 \mathrm{M}$ PBS and digested in $20 \mathrm{~mL}$ of $0.1 \% \mathrm{w} / \mathrm{v}$ collagenase B solution (Roche, Germany), in a $5 \% \mathrm{CO}_{2}$ incubator at $37^{\circ} \mathrm{C}$ for 45 minutes. Next, the samples were centrifuged at $1,400 \mathrm{rpm}$ for 10 minutes; the supernatant was discarded, and the pellet was seeded and cultured in T75 flasks containing basal low-glucose Dulbecco's modified Eagle's medium (DMEM; Gibco, USA) with gentamicin $\left(60 \mu \mathrm{g} \mathrm{L}^{-1}\right)$, penicillin $\left(100 \mathrm{U} \mathrm{mL}^{-1}\right)$, streptomycin $\left(100 \mu \mathrm{g} \mathrm{mL}^{-1}\right)$, and amphotericin $\left(25 \mu \mathrm{g} \mathrm{mL}^{-1}\right)$ (PSA, Sigma-Aldrich, USA)], and supplemented with $10 \%$ fetal bovine serum (Soralis, Brazil). Culture medium was changed twice a week, and cells were cultured until 80-90\% confluence. Cells were then trypinized and passage.

\section{Osteogenic differenciation}

The third passage cells were induced by lineage-specific induction factor to osteoprogenitor cells (OC-AD-MSCs) according to ALVES et al. (2015a). The AD-MSCs were seeded in T75 flasks at density of $1 \times 10^{4}$ cells $\mathrm{cm}^{-1}$ in DMEM with ascorbic acid $\left(50 \mu \mathrm{g} \mathrm{mL} \mathrm{mL}^{-1}\right), \quad$-glycerophosphate $(10 \mathrm{mM})$ (Sigma, USA), dexamethasone $(0.1 \mu \mathrm{M})$ (Aché, Brazil), and 10\% fetal bovine serum (Soralis, Brazil).

To verify osteogenic differentiation of AD-MSCs after 21 days of cultivation in osteogenic medium, we performed relative quantification of gene transcripts of osterix (OSX), bone sialoprotein (BSP), and osteocalcin (OC) by real time RT-PCR using the $2^{\text {-delta delta } \mathrm{CT}}$ method. The RT-PCR reactions were performed using $2 \mu \mathrm{g}$ of cDNA, $5 \mathrm{pM}$ of each primer, and $12.5 \mu \mathrm{L}$ of the SYBR Green reagent (SuperScript $^{\mathrm{TM}}$ III Platinum ${ }^{\circledR}$ Two-Step qRT-PCR Kit with SYBR Green, Invitrogen, CA, USA) in a final volume of $25 \mu \mathrm{L}$ per well, and using the SmartCycler System apparatus. Parameters used for amplification were as follows: $50^{\circ} \mathrm{C}$ for 120 seconds, $95^{\circ} \mathrm{C}$ for 150 seconds, and 45 cycles of $95^{\circ} \mathrm{C}$ for 15 seconds and $60^{\circ} \mathrm{C}$ for 30 seconds. We used the primers F-5'-ACGACACTGGGCAAAGCAG-3' and R-5'CATGTCCAGGGAGGTGTAGAC-3' for OSX, F-5'-TTGCTCAGCATTTTGGGAAT-3' and R-5'AACGTGGCCGATACTTAAAGAC-3' for BSP, and F-5'-GAGGGCAGCGAGGTGGTGAG and R-5'TCAGCCAGCTCGTCACAGTTGG-3' for OC. The glyceraldehyde 3-phosphate dehydrogenase gene (GAPDH) was used as housekeeping control, with the primers F- 5'-CCATCTTCCAGGAGCGAGGAT-3' and R- 5' (ALVES et al., 2015a). Canine osteoblasts were used as the expression standard of the transcripts.

Confirmation of osteogenesis was also done by means of Von Kossa highlight ECM calcification.

\section{Creation of bone defects and OC-AD-MSCS implantation}

For the evaluation of cell therapy, we have used 10 healthy male mongrel dogs (approximatively 2 two-year-old, body weight of $25 \pm 5,6 \mathrm{~kg}$ ). Dogs were randomly divided into two experimental groups: the negative control group $(\mathrm{C}-)$, animals with unfilled critical bone defects $(n=5)$ or the group treated with OC-AD-MSCs (OC), animals with critical bone defects treated with a single local injection of OCAD-MSCs at the end of the surgery $(n=5)$. The positive control $(\mathrm{C}+)$ was performed in all animals using the contralateral radius $(\mathrm{n}=10)$, with the critical defect filled with the bone fragment removed from the ostectomy.

Animals were operated under inhalation general anesthesia (isoflurane). To control pain and inflammation we administered $3 \mathrm{mg} \mathrm{kg}^{-1} \mathrm{SC}$ TID tramadol (Tramadol Hydrochloride, Teuto, Brazil) and $0.2 \mathrm{mg} \mathrm{kg}^{-1}$ IM SID meloxicam $(0.2 \%$ injectable Maxicam, Ouro Fino, Brazil) for five consecutive days, as well as antibiotic therapy with cephalexin (30 $\mathrm{mg} \mathrm{kg}^{-1} \mathrm{VO}$, BID) for seven consecutive days. Critical bone defect was created according to KANG et al. (2012) and ALVES et al. (2015b) by removing 
a bone fragment from the middle third of the radius with an extension corresponding to 1.5 times the diameter of the bone. Bone stabilization was performed with an F318 steel bridge plate positioned on the cranial surface of the radius and fixed with six bicortical screws. After bone fixation, the defect was treated according to the experimental group. For the OC group, $3 \times 10^{6}$ cells $\mathrm{cm}^{-3}$ of defect were implanted according to ARINZEH et al. (2003).

Radiographic evaluations were performed in the mid-lateral and craniocaudal radiographic projections of both radii immediately before and after the operation, and at $15,30,45,60,75$, and 90 days after surgery. Craniocaudal projection was used for monitoring the bone alignment and the mid-lateral projection, to measure areas of bone growth in the lines of osteotomy. Measurements were performed using Digimizer Image Analysis software. The areas corresponding to bone growth were expressed as a percentage relative to the total area of the bone defect for each animal (ALVES et al., 2015b).

Animals were euthanized using propofol to induce cardiac arrest, followed by administration of $40 \mathrm{ml}$ of potassium chloride. The radio and ulnae were collected, dissected, and fixed in $10 \%$ buffered formalin for 30 days. Densitometric evaluation was performed using a dual energy X-ray densitometer (DXA Densitometer, DPX-Alpha Lunar model). Bone mineral density $\left(\mathrm{g} \mathrm{cm}^{-2}\right)$ was measured in the region corresponding to bone defects with an incidence on mid-lateral projection. Density values of each defect were converted to percentage of region corresponding to the defects treated with autograft, considered 100\%. (ALVES et al., 2015b).

For histological and histomorphometric evaluation, radii and ulnae were sectioned transversely at the screws adjacent to the failure. The central bone segment containing the defect was subjected to a demineralization protocol with $50 \% \mathrm{v} / \mathrm{v}$ aqueous formic acid and $9 \% \mathrm{w} / \mathrm{v}$ sodium citrate for 90 days, changed every four days. After this period, a longitudinal section of bone segment corresponding to the defect was removed, and each half was processed by routine paraffin embedding. Histological sections $(5 \mu \mathrm{m})$ were obtained from each block and stained with hematoxylin-eosin. Slides were assessed qualitatively by optical microscopy. The area of new bone formation was quantified with the aid of an ocular micrometer, having a graticule with 121 points and an objective of four, covering the entire length of the defect. The area of new bone formation was expressed relatively to the total defect area of each animal. We also quantified the number of blood vessels per field in 12 fields taken in the defect area by microscopy using a $20 \mathrm{x}$ objective.

We used a completely randomized design with a paired positive control. Data were subjected to analysis of variance (ANOVA), and the means were compared by the Student Newman Keuls (SNK) test using Graphpad Instat 3 software. Differences were significant if $\mathrm{P}<0.05$.

\section{RESULTS}

After 21 days of culture in osteogenic medium, AD-MSCs formed mineralized nodules (Figure 1) and an increase in the relative expression of gene transcripts for osterix, bone sialoprotein, and osteocalcin were observed (Figure 1).

The negative control $(\mathrm{C}-)$ and the group treated with OC-AD-MSCs (OC) showed partial bone filling of the defect (a maximum of $56.68 \%$ and $63.72 \%$, respectively), without the formation of a bone bridge between the ends; the positive control $(\mathrm{C}+)$ showed complete bone healing in all animals at 90 days (Figure 2). The areas of bone filling in the $\mathrm{C}$ - and OC groups were significantly lower than those of the positive control $(\mathrm{C}+)$ at all time points tested. The OC group showed greater bone filling than the C- group, at 15 days post-operation; however, no difference was observed at the subsequent evaluation times (Figure 3).

Histological evaluation of $\mathrm{C}$ - and $\mathrm{OC}$ groups showed new bone formation in the defect ends toward the center, without a union between them. The neoformed bone in all defects of $\mathrm{C}$ - and $\mathrm{OC}$ groups was spongy (Figure 2), with thick trabeculae predominantly covered with bulky osteoblasts. Predominance of active osteocytes was also found in the neoformed bone tissue in extended gaps. Histomorphometric and densitometric evaluations revealed similar areas of new bone formation and bone mineral mass between groups $\mathrm{C}$ - and $\mathrm{OC}$ at 90 days post operatively (Figure 3 ).

We have observed that the center of the defects in the $\mathrm{C}$ - and $\mathrm{OC}$ groups were formed by disorganized fibrous connective tissue; however, in the defects of the MSC group, connective tissue was less dense, with multiple cell clusters arranged in small caliber vascular channels lined with endothelial cells. Neovascularization was significantly greater in the OC group compared to the C- group, corresponding to an average value of $6.75 \pm 2.39$ vessels per field in the OC group and $1.99 \pm 0.97$ in C- group (Figure 4).

There was no new bone formation at the center of the defects in any of samples from 

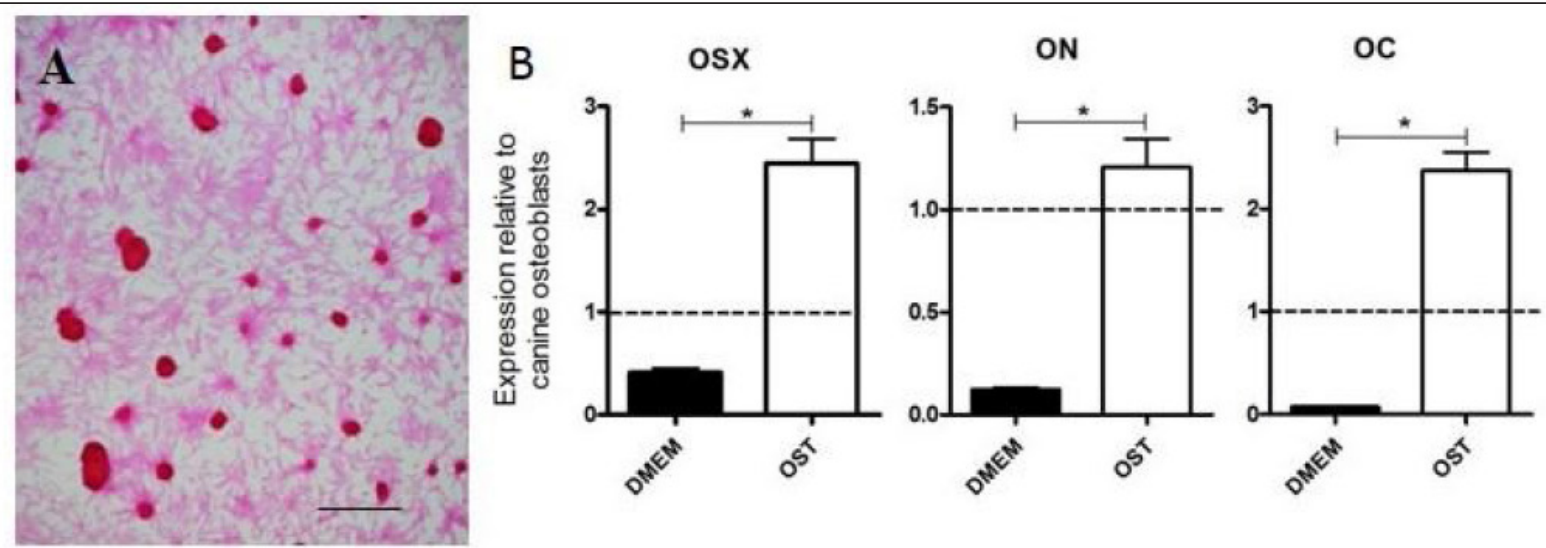

Figure 1 - Micrograph of mineralized nodules in AD-MSC cultures undergoing osteogenic differentiation after 21 days Bar = 350 $4 \mathrm{~m}$ Von Kossa staining (A). Relative expression of gene transcripts for osterix (OSX), bone sialoprotein (BSP), and osteocalcin (OC) in undifferentiated AD-MSC cultures (DMEM) and differentiated cultures after 21 days (OST). The dotted line (1) depicts the expression level in osteoblasts.

the C- and OC groups. There was complete bone healing in the defects treated with autogenous bone $(\mathrm{C}+)$ at 90 days post-operation. The presence of inflammatory infiltrate was not observed in any of the defects of all groups.

\section{DISCUSSION}

For the clinical use of a new therapy for bone regeneration, prior experimental study in subjects, preferably of the same species, is required. As the biological response may vary according to species, extrapolation from one species to another is not allowed; for this reason, we selected the dog as an experimental model. Dogs are widely used in bone regeneration studies and may be used as a model for preclinical studies when proposing an application for use in human patients.

The partial filling of bone defects observed at 90 days post-operation in the negative control group (C-) (Figures 2, 3) demonstrated that the bone defect was sufficient to cause a critical defect that required support for regeneration, and thus validated the methodology used. A bone defect segment 1.5fold greater than the diaphyseal diameter exceeds the bone regenerative capacity in dogs with skeletal maturity, resulting in non-union (KANG et al., 2012; ALVES et al., 2015b).

Complete bone regeneration was observed at 90 days post-operation in all defects treated by autograft (C+ group) (Figures 2, 3); this showed that all animals had normal bone regeneration capacity and that the bone stabilization technique was adequate.
Improper bone fixing is a major cause of problems in bone consolidation and the most frequent cause of non-union fractures in small animals (KRAUS \& BAYER, 2012). Therefore, it is necessary to ensure adequate bone stabilization when studying new therapies to promote bone regeneration.

A larger neoformed bone area was observed radiographically on group $\mathrm{OC}$, at 15 days post-operation compared to that of the $\mathrm{C}$ - group (Figure 3). This showed that OC-AD-MSCs were able to enhance bone healing in this evaluation period. The presence of osteoprogenitor cells and mesenchymal stem cells (MSCs), with the ability to differentiate into bone cells, is probably the predominant factor contributing to the increase in osteogenic activity and consequently, repair of bone injury. When MSCs are added to a bone injury site, they can differentiate into osteoblasts and increase bone matrix synthesis (KANG et al., 2012; ARINZEH et al., 2003). MSCs have the capacity to differentiate into any mesenchymal cell such as tenocytes, myoblasts, adipocytes, and chondrocytes (STRIOGA et al., 2012). To maximize osteogenic differentiation, in vitro differentiation is recommended before clinical use (LIU et al., 2013), as was performed in the present study (Figure 1). The formation of mineralized nodules and increases in expression of OSX, BSP, and OC (Figure 1) are considered reliable markers of osteogenic differentiation (ALVES et al., 2014; ALVES et al., 2015a).

Similarity in new bone formation area and bone mineral mass between $\mathrm{C}$ - and $\mathrm{OC}$ 


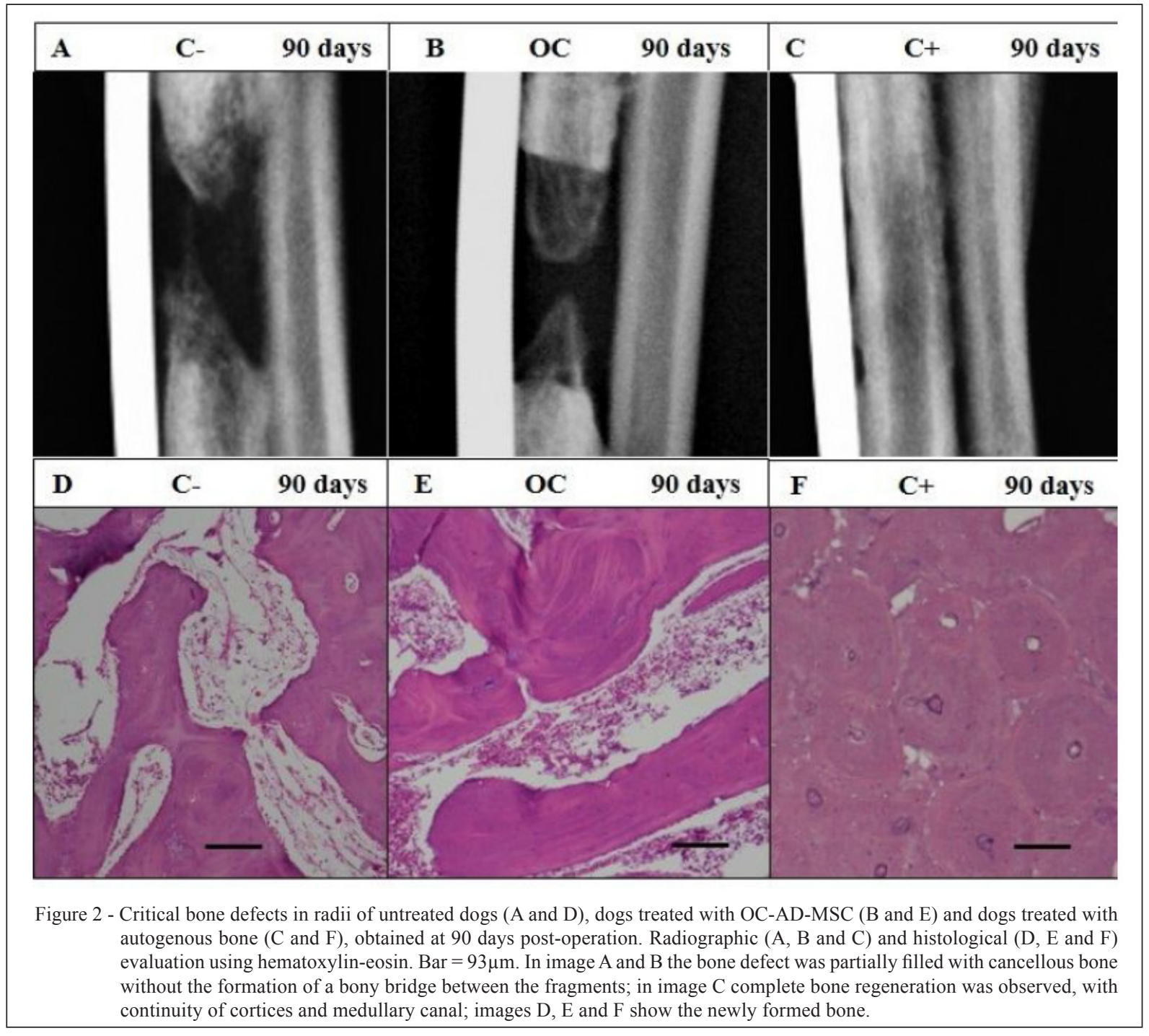

groups, obtained by the histomorphometric and densitometric evaluations (Figure 3), showed that a single application of OC-AD-MSCs at the defect focus did not increase osteogenesis at 90 days postoperation. Number of cells used is a factor that may have contributed to this low bone regeneration efficiency. In theory, the use of more cells would result in greater matrix production and better bone regeneration; however, more cells require longer time for expansion in vitro before therapeutic use, thus resulting in a longer time to perform the treatment. For this reason, there is a need to find the minimum number of cells per volume of bone defect able to promote effective bone regeneration. Most studies have been successful using $10^{6} \mathrm{OC}-\mathrm{AD}$ MSC $\mathrm{cm}^{-3}$ of defect (ZHU et al., 2010), similar to the number of cells used in this study. Some studies have suggested the use of fewer cells $\left(10^{5} \mathrm{MSC} \mathrm{cm}^{-3}\right.$ of defect) (BELOTI et al., 2012); however, other studies recommend higher cell numbers of $10^{7} \mathrm{MSC}$ $\mathrm{cm}^{-3}$ (LIU et al., 2013) and $10^{8} \mathrm{MSC} \mathrm{cm}^{-3}$ for effective bone regeneration (WU et al., 2006).

Another factor that may be responsible for the low efficiency of OC-AD-MSCs in the regeneration of critical bone defects is the absence of a scaffold for cell adhesion and conduction. Studies showed that the presence of a scaffold for osteoconduction favors the regeneration of critical bone defects (ARINZEH et al., 2003; KANG et al., 2012; LIU et al., 2013).

Allogeneic MSCs, differentiated or not, have immunomodulatory capacity (NIERMEYER 


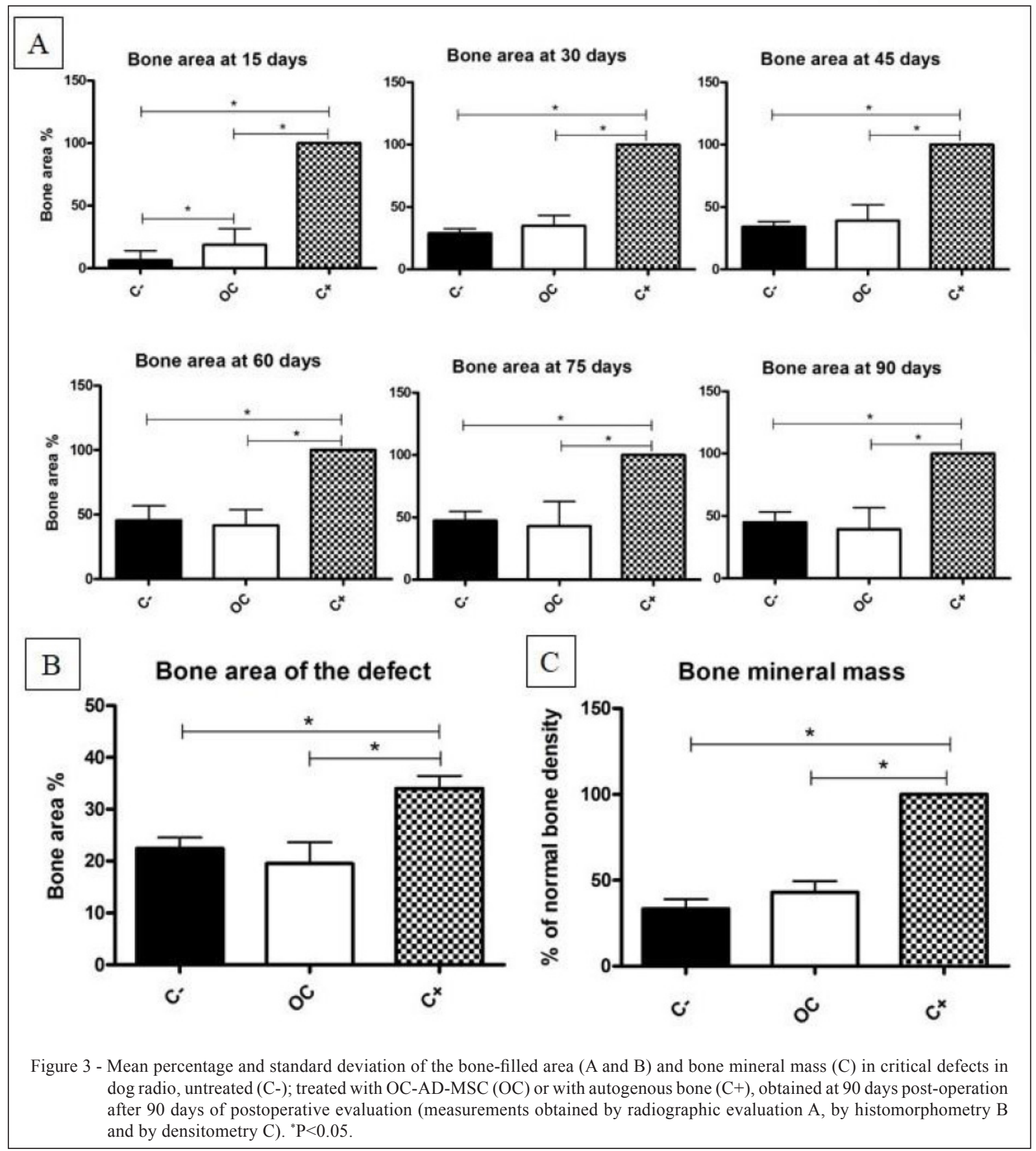

et al., 2007) and are not rejected when implanted in immunologically compatible individuals (ARINZEH et al., 2003). However, it is known that there is a gradual reduction in the number of MSCs in the focus of the injury over time (NANDOE TEWARIE et al., 2009), which may explain the transient beneficial effect of OC-AD-MSCs observed in this study. It is believed that therapy using multiple applications of
OC-AD-MSCs may result in an effective treatment with complete bone regeneration, but to prove this hypothesis another study is required. The therapeutic use of allogeneic cells, as performed in this study, showed advantages over the use of autogenous cells; when working with allogeneic cells it is possible to create cryopreserved cell banks, which enables a readily available reserve for clinical use 

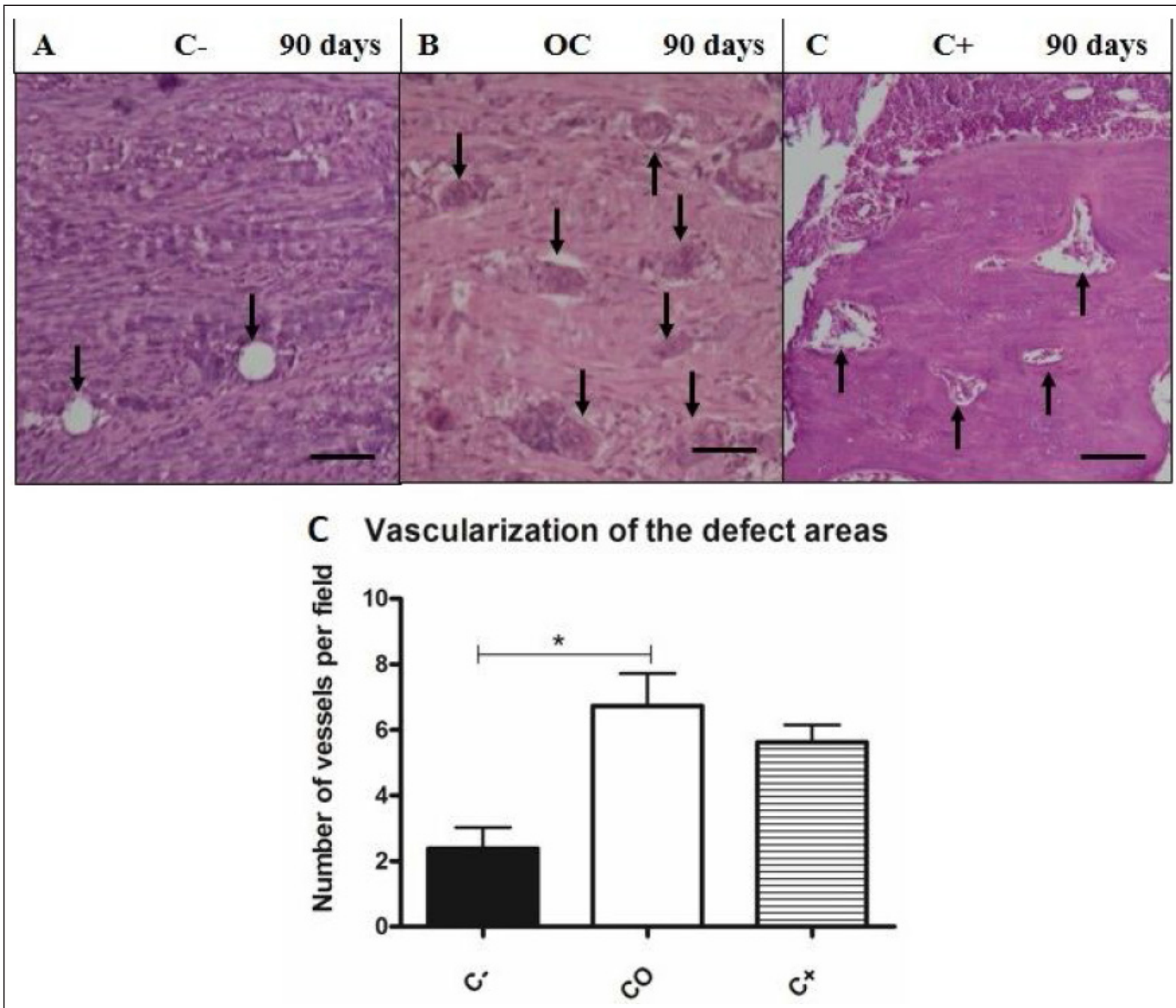

Figure 4 - Micrograph of the center of critical bone defects in dog radio, untreated (A), treated with OC-AD-MSC (B) or autogenous bone $(\mathrm{C}+), 90$ days after surgery. The presence of fibrous connective tissue in groups $\mathrm{C}$ - and $\mathrm{OC}$ and increased vascularization in the OC group is shown by hematoxylin-eosin staining. Bar $=186 \mu \mathrm{m}$. Image (D) shows the mean percentage and standard deviation of the number of vessels $\mathrm{p}$ er field in the center of critical defects in dog radio in the C-, OC and C+ groups at 90 days postoperation (measurements obtained by histomorphometry). ${ }^{*} \mathrm{P}<0.05$.

in emergency cases (KRAUS \& KIRKER-HEAD, 2006). In addition, young donors in perfect health can be selected, which resulted in the isolation of MSCs with high regenerative potential, thus allowing therapeutic use in geriatric patients and those with other conditions that may affect the regenerative potential of autogenous MSCs, such as the presence of genetic diseases.

The increased neovascularization observed in the OC group at 90 days post-operation (Figure 4) is another factor that may favor bone healing. In theory, increased tissue vascularization results in greater perfusion and enhanced delivery of nutrients and other cells, providing a microenvironment more favorable for bone regeneration.

As the major limitation of the present study, we had only one application of osteoprogenitor cells, which seem insufficient for complete boner regeneration. Phenotypic characterization of osteogenic cells would bring interesting information about these cells; however, it was not performed. As a positive point of the study, the application of osteoprogenitor cells improve bone regeneration temporarily, suggesting that multiple application of these cells could be an efficient therapy for critical bone defects in dogs. 


\section{CONCLUSION}

Based on the conditions of this study, we can say that treatment with OC-AD-MSCs increased newly formed bone areas at 15 days post-operation, but this was not enough for complete bone union in critical bone defects in dog radii at 90 days.

\section{BIOETHICS AND BIOSSECURITY COMMITTEE APPROVAL}

This study was conducted in accordance with the international standards of animal welfare after approval by the Ethics Committee in Animal Experimentation of UFMG (protocol no. 157/2009).

\section{ACKNOWLEDGEMENTS}

The authors thank the Fundação de Amparo à Pesquisa do Estado de Minas Gerais (FAPEMIG) for funding the study, the Conselho Nacional de Desenvolvimento Científico e Tecnológico (CNPq) for the doctoral grant, the Veterinary School of the Universidade Federal de Minas Gerais (UFMG) and The Veterinary School of the Universidade de Uberaba (UNIUBE) for the support needed to conclude the present study.

\section{REFERENCES}

ALVES, E.G.L. et al. Comparison of the osteogenic potential of mesenchymal stem cells from the bone marrow and adipose tissue of young dogs. BMC Veterinary Research, v.10, p.110, 2014. Available from: <http://www.ncbi.nlm.nih.gov/ pubmed/25178540>. Accessed: Aug. 03, 2015. doi: 10.1186/ s12917-014-0190-y.

ALVES, E.G.L. et al. Effect of ionic product of bioglass $60 \mathrm{~S}$ in osteogenic differentiation of mesenchymal stem cells from the adipose tissue do dogs. Arquivo Brasileiro de Medicina Veterinária e Zootecnia, v.67, p.969-978, 2015a. Available from: $\quad<\mathrm{http}: / /$ cpro4576.publiccloud.com.br:8080/editora// upload/trabalho/10086-21355.pdf>. Acessed: Aug. 03, 2015. doi: $10.1590 / 1678-4162-7539$.

ALVES, E.G.L. et al. Porous matrix of BG60S in the treatment of critical bone defects in the radius of dogs. Arquivo Brasileiro de Medicina Veterinária e Zootecnia, v.67, p.993-1002, 2015b. Available from: <http://cpro4576.publiccloud.com.br:8080/ editora//upload/trabalho/10301-21358.pdf>. Accessed: Aug. 03, 2015. doi: 10.1590/1678-4162-7744.

ARINZEH, T.L. et al. Allogeneic mesenchymal stem cells regenerate bone in a critical-sized canine segmental defect. Journal of Bone \& Joint Surgery, v.85, p.1927-1935, 2003. Available from: <http://jbjs.org/content/85/10/1927>. Accessed: Aug. 03, 2015.

BELOTI, M.M. et al. The influence of osteoblast differentiation stage on bone formation in autogenously implanted cell-based poly(lactide-co-glycolide) and calcium phosphate constructs. Tissue Engineering, v.18, p.999-1005, 2012. Available from: $<$ http://www.ncbi.nlm.nih.gov/pubmed/22150110>. Accessed: Aug. 03, 2015. doi: 10.1089/ten.TEA.2011.0405.

KANG, B.J. et al. Comparing the osteogenic potential of canine mesenchymal stem cells derived from adipose tissues, bone marrow, umbilical cord blood, and Wharton's jelly for treating bone defects. Journal Veterinary Science, v.13, p.299-310, 2012. Available from: <http://www.ncbi.nlm.nih.gov/pmc/ articles/PMC3467406/>. Accessed: Mar. 23, 2016. doi: 10.4142/ jvs.2012.13.3.299.

KRAUS, K.H.; KIRKER-HEAD, C. Mesenchymal stem cells and bone regeneration. Veterinary Surgery, v.35, p.232-242, 2006. Available from: <http://onlinelibrary.wiley.com/doi/10.1111/ j.1532-950X.2006.00142.X/abstract>. Accessed: Aug. 03, 2015. doi: 10.1111/j.1532-950X.2006.00142.x.

KRAUS, K.H.; BAYER, B.J. Delayed unions, nonunions, and malunions. In: TOBIAS, K.M.; JOHNSTON, S.A. Veterinary surgery small animal. St. Louis: Saunders, 2012. Cap.46, p.647-656.

NIERMEYER, P. et al. Comparison of immunological properties of bone marrow stromal cells and adipose tissue-derived stem cells before and after osteogenic differentiation in vitro. Tissue Engineering, v.13, p.111-121, 2007. Available from: <http://www. ncbi.nlm.nih.gov/pubmed/17518585>. Accessed: Aug. 03, 2015. doi: 10.1089/ten.2006.0114.

LIU, G. et al. Bone regeneration in a canine model using allogeneic adipose derived stem cells and coral scaffold. Biomaterials, v.34, p.2655-2664, 2013. Available from: <http://www.ncbi.nlm.nih. gov/pubmed/23343633>. Accessed: Aug. 03, 2015. doi: 10.1016/j. biomaterials.2013.01.004.

NANDOE TEWARIE, R.D. et al. Bone marrow stromal cells elicit tissue sparing after acute but not delayed transplantation into the contused adult rat thoracic spinal cord. Journal Neurotrauma, v.26, p.2313-2322, 2009. Available from: < http://online.liebertpub. com/doi/abs/10.1089/neu.2009.0987>. Accessed: Mar. 28, 2016. doi: $10.1089 /$ neu.2009.0987.

STRIOGA, M. et al. Same or not the same? Comparison of adipose tissue-derived versus bone marrow-derived mesenchymal stem and stromal cells. Stem Cells and Development, v.21, p.2724-2752, 2012. Available from: <http://www.ncbi.nlm.nih. gov/pubmed/22468918>. Accessed: Aug. 03, 2015. doi: 10.1089/ scd.2011.0722.

WU, W. et al. Bone marrow-derived osteoblast seeded into porous beta-tricalcium phosphate to repair segmental defect in canine's mandibular. Turkish Journal of Trauma \& Emergency Surgery, v.12, p.268-276, 2006. Available from: <http://www. journalagent.com/travma/pdfs/UTD_12_4_268_276.pdf $>$. Acessed: Aug. 03, 2015.

ZHU, L. et al. Enhanced healing of goat femur-defect using BMP7 gene-modified BMSCs and load-bearing tissueengineered bone. Journal of Orthopaedic Research, v.28, p.412-418, 2010. Available from: <http://www.ncbi.nlm.nih.gov/ pubmed/19725097>. Accessed: Aug. 03, 2015. doi: 10.1002/ jor.20973. 